\title{
Effect of Coronary Tortuosity on Exercise Stress Test
}

\author{
Koroner Tortiyozitenin Egzersiz Stres Testi Üzerindeki Etkisi
}

\begin{abstract}
Introduction: Coronary tortuosity (CT) is a common anatomical finding during coronary angiography (CA); however, its aetiology and clinical importance have not been clearly defined. We aimed to evaluate the effect of the presence or severity of $\mathrm{CT}$ and effect of the sigma-shaped right coronary artery (RCA) on the exercise stress test (EST).

Methods: The study included 175 patients who underwent CA due to cardiac symptoms and positive EST and had no obstructive coronary artery disease in a single centre between 2017 and 2018 June. The patients were divided into two groups: Group 1, patients with CT ( $n=88)$, and group 2, patients without $\mathrm{CT}(\mathrm{n}=87)$. The patients were also categorised as low and moderate-to-high risk based on Duke treadmill score (DTS).

Results: The running distance and DTS were lower, and the rate of sigma-shaped RCA was higher in the CT group $(p<0.006)$. The DTS was lower $(p=0.024)$ in the presence of tortuosity in the left anterior descending coronary artery and negatively influenced as the number of coronary arteries affected by tortuosity increased $(p<0.001)$. Based on the DTS score, patients with moderate-to-high risk have a higher number of vessels affected by tortuosity, involvement of left anterior descending coronary artery, and proportion of sigma-shaped RCA $(p<0.001)$.

Conclusion: In the presence of $\mathrm{CT}$, the rate of positivity is significantly higher, and the DTS is lower in the stress test.

Keywords: Coronary artery, Duke score, exercise stress test, sigma-shaped RCA, tortuosity
\end{abstract}

ÖZ
Amaç: Koroner tortiyozite (KT), koroner anjiyografi (KA) sırasında karşılașılan yaygın bir anatomik bulgudur; ancak etiyolojisi ve klinik önemi net olarak tanımlanmamıștır. Biz de KT varlığı ve şiddeti ile sigma şekilli sağ koroner arter (SKA) varlığının egzersiz stres testi (EST) üzerine etkisini incelemeyi amaçladık.

Yöntemler: Çalıșmaya 2017-2018 Haziran tarihleri arasında tek bir merkezde kardiyak semptomlar ve pozitif EST nedeniyle KA uygulanan ve obstrüktif koroner arter hastalığı bulunmayan 175 hasta dahil edildi. Hastalar iki gruba ayrıldı: Grup 1, KT'si olan hastalar ( $n=88$ ) ve grup 2 , KT'si olmayan hastalar $(n=87)$. Ayrıca hastalar Duke koșu bandı skoruna (DTS) göre sınıflandırıldı.

Bulgular: KT grubunda koşma mesafesi ve DTS daha düşüktü ve sigma şeklindeki SKA oranı daha yüksekti $(p<0,006)$. Sol ön inen koroner arterde KT varlığında DTS'nin daha düşük $(p=0,024)$ olduğu ve tortiyoziteden etkilenen koroner arterlerin sayısı arttıkça DTS'nin olumsuz etkilendiği bulundu $(p<0,001)$. DTS skoruna göre orta-yüksek risk grubunda olan hastalarda tortiyoziteden etkilenen damar sayısı ile sol ön inen koroner arter tutulumu ve sigma şekilli SKA oranı daha yüksekti $(p<0,001)$.

Sonuç: KT varlığında, stres testinde pozitiflik oranı daha yüksektir ve DTS daha düșüktür.

Anahtar Kelimeler: Koroner arter, Duke skoru, egzersiz stres testi, sigma RCA, tortiyozite

\section{Introduction}

Coronary tortuosity (CT) is a common anatomical finding during coronary angiography (CA); however, its aetiology and clinical importance have not been clearly defined (1). CT has been shown to be associated with advanced age, hypertension, atherosclerosis and diabetes mellitus and to be more common in atherosclerotic arteries $(2,3)$. Degeneration of elastin in the arterial wall and chronic vascular pressure load also play a significant role in the development of $C T(4,5)$. Therefore, it has been suggested that the CT is an arterial remodelling caused by hypertension, that is, an adaptation of coronary arteries to hypertension (6). Besides, hypertension severity was an independent risk factor for $\mathrm{CT}$ in women (2).

Patients with CT often complain of chest pain during exercise and the pain disappears during rest (4). Although patients with severe CT and normal coronary arteries exhibit myocardial perfusion defects, the role
Address for Correspondence/Yazıșma Adresi: Yakup Alsancak MD, Necmettin Erbakan University Meram Faculty of Medicine, Department of Cardiology, Konya, Turkey

Phone: +90 5069101404 E-mail: dryakupalsancak@gmail.com ORCID ID: orcid.org/0000-0001-5230-2180

Cite this article as/Atıf: Alsancak Y, Gürbüz AS, Özçelik A, İçli A. Effect of Coronary Tortuosity on Exercise Stress Test. İstanbul Med J 2020; 21(6): 408-412.

(C) Copyright 2020 by the University of Health Sciences Turkey, Istanbul Training and Research Hospital/istanbul Medical Journal published by Galenos Publishing House.

(C) Telif Hakkı 2020 Sağılk Bilimleri Üniversitesi İstanbul Ĕğitim ve Araştırma Hastanesi/Istanbul Tıp Dergisi, Galenos Yayınevi tarafından basılmıștır.

Received/Geliș Tarihi: 15.06 .2020 Accepted/Kabul Tarihi: 08.08.2020 
of tortuosity in angina is not fully known (7). It has been suggested that myocardial blood flow reserves might be decreased in patients with ischaemia but not obstructive coronary artery disease, and severe CT may be a particularly important cause of ischaemia (8). As such, CT can not be considered as a completely benign coronary anomaly.

In practice, the exercise stress test (EST) is one of the most commonly used methods to evaluate ischaemia related to coronary artery disease. This study aimed to evaluate the effect of the presence or severity of CT and the effect of the sigma-shaped right coronary artery (RCA) linked to RCA tortuosity on the EST in patients who underwent CA after positive stress test and were found to have normal coronary anatomy during angiography.

\section{Methods}

\section{Study Population}

The study included patients who were admitted to our cardiology clinic because of chest pain, shortness of breath, or any angina equivalent and who were indicated for exercise tests and could exercise on a treadmill table. Subsequently, 175 patients who underwent CA due to positive EST but without coronary artery disease during angiography between June 2017 and June 2018 in our department were included. The patients were divided into group 1, patients with $\mathrm{CT}(\mathrm{n}=88)$, and group 2, patients without CT as control group $(n=87)$. Demographic data, laboratory findings and echocardiographic findings were recorded. Patients with chronic disease (chronic renal failure, malignancy, connective tissue disease), moderate-to-severe heart valve disease, active infection, previously known coronary artery disease, coronary artery ectasia, myocardial bridge, myocarditis or pericarditis, hypertrophic cardiomyopathy, or pulmonary hypertension were excluded. The study protocol was approved by the Necmettin Erbakan University Meram Faculty of Medicine Institutional Ethics Board (decision no: 89, date: 24.05.2019), and written informed consent was obtained from all patients.

\section{Exercise Stress Test}

The records were examined for the patients who were diagnosed with CT and underwent an EST using the Philips StressVue System (Philips Healthcare, Andover MA, USA). Blood pressure, heart rate and standard 12-lead electrocardiograms were recorded before the test, and the measurements were repeated intermittently. The patients' angina status and ST-segment deviations were examined. The maximum ST-segment deviation was measured at $80 \mathrm{~ms}$ after the J point. Patients were categorised based on the Duke treadmill score (DTS) as follows: low risk (DTS $\geq+5)$, moderate risk $(-10<$ DTS $\leq+4)$ and high risk (DTS <-11) (9). Based on this risk assessment, the presence of tortuosity, RCA shape and the number of coronary arteries affected by tortuosity were compared.

The DTS was calculated using the following formula (10):

DTS = Exercise time-( $5 \times$ ST deviation)-(4×Angina index).

Angina index was scored as 2, 1 and 0 for exercise restriction, without exercise restriction, and no pain, respectively.

\section{Evaluation of Coronary Anatomy}

Diagnostic CA was performed using the radial or femoral artery according to the operator's preference and patient's clinical characteristics. Angiographic images were recorded after intracoronary nitroglycerin administration based on the patient's blood pressure. The CA images were separately evaluated by two cardiologists; the patient's CT status and RCA shape were recorded.

\section{Coronary Tortuosity and Right Coronary Artery Shape}

CT was defined as the presence of more than three $45^{\circ}$ deviations in the main coronary arteries [RCA or left anterior descending (LAD) and circumflex coronary arteries] at both systole and diastole (11). Sigmashaped RCA was determined by two steps in the simple left anterior oblique projection-at $25^{\circ}-35^{\circ}$-usually with no craniocaudal angulation. First, the two outermost points of the RCA were combined with an imaginary line, and the maximal arterial diameter was calculated. Second, the length between the imaginary line and coronary artery was measured. If the distance was longer than the maximal measured arterial diameter, it was categorised as sigma-shaped RCA. The RCA was considered C shaped if it did not meet the criteria of the sigma shape or had only one lateral point (12).

\section{Statistical Analysis}

SSPS ${ }^{\circledR}$ version 16.0 statistical package programme (SPSS Inc., Chicago, IL, United States) was used for statistical analyses. Quantitative variables fitting into normal distribution and categorical variables were presented as mean \pm standard deviation and number and percentages, respectively. Normality of distribution was evaluated using the Kolmogorov-Smirnov test. The mean values of continuous variables were compared between independent groups using the Student t-test, One-Way ANOVA, or Kruskal-Wallis test as appropriate. The chi-squared test was performed to compare the study groups in terms of categorical variables. Statistical significance was determined for $p<0.05$.

\section{Results}

The mean age of the study population was $62.1 \pm 10$ years; the majority of the participants were women (56.5\%). The rate of female sex was higher in the CT group but not statistically significant. The rates of smoking and hypertension were significantly higher in the CT group ( $p=0.029$ and $p=0.043$, respectively). No correlation was found between the number of tortuous coronary arteries and sex, age, smoking, diabetes mellitus, or hypertension $(p>0.05)$. No significant difference in the haematological or biochemical findings was found between the two groups. Pulmonary arterial pressures and ejection fractions were similar; the left atrial diameter was significantly higher in patients with $\mathrm{CT}(\mathrm{p}=0.038)$. Table 1 shows the patient's demographic and laboratory findings.

The stress test results showed that the running distance was lower in the CT group ( $p=0.004)$, which had a lower DTS $(p<0.001)$. As expected, the rate of sigma-shaped RCA was higher in the CT group $(p=0.005)$. In the subgroup analyses, $34.3 \%(n=60)$ of the total study population had sigma-shaped RCA, and the DTS was lower in these patients $(p<0.001)$. The DTS was lower $(p=0.024)$ in the presence of tortuosity in the LAD coronary artery and negatively influenced as the number of coronary 
arteries affected by tortuosity increased $(p<0.001)$. The rate of sigmashaped RCA and the number of patients with tortuous arteries were higher in moderate-to-high risk group $(p<0.001)$. The relationships between the CT status and EST results are shown in Tables 2 and 3.

Table 1. Demographic, clinical and laboratory characteristics of the study population

\begin{tabular}{|c|c|c|c|}
\hline & $\begin{array}{l}\text { Control group } \\
n=87\end{array}$ & $\begin{array}{l}\text { Tortuosity } \\
\text { group } \\
n=88\end{array}$ & $\mathrm{p}$ \\
\hline Age (years) & $61.4 \pm 10.6$ & $61.7 \pm 10.8$ & 0.841 \\
\hline Sex (female), n (\%) & $40(45.9)$ & $50(56.8)$ & 0.058 \\
\hline DM, n (\%) & $21(24.1)$ & $23(26.1)$ & 0.761 \\
\hline Hypertension, $\mathbf{n}(\%)$ & $47(54)$ & $60(68)$ & 0.043 \\
\hline Smoking, n (\%) & $20(23)$ & $35(40)$ & 0.029 \\
\hline LVEF (\%) & $59.2 \pm 4.1$ & $58.6 \pm 3.7$ & 0.300 \\
\hline LA diameter (cm) & $3.47 \pm 0.32$ & $3.78 \pm 0.31$ & 0.038 \\
\hline Systolic PAB (mmHg) & $27.5 \pm 3.8$ & $28.3 \pm 4.7$ & 0.276 \\
\hline Creatinine (mg/dL) & $0.79 \pm 0.19$ & $0.78 \pm 0.17$ & 0.582 \\
\hline $\mathrm{Hb}(\mathrm{g} / \mathrm{dL})$ & $13.4 \pm 1.8$ & $13.4 \pm 1.7$ & 0.952 \\
\hline Platelet $\left(10^{3} / \mathrm{mm}^{3}\right)$ & $254.3 \pm 59.7$ & $255.3 \pm 60.0$ & 0.917 \\
\hline Leukocyte $\left(10^{3} / \mathrm{mm}^{3}\right)$ & $7.51 \pm 2.41$ & $7.53 \pm 2.40$ & 0.947 \\
\hline FBG $(\mathrm{mg} / \mathrm{dL})$ & $103.3 \pm 25.9$ & $108.2 \pm 33.2$ & 0.288 \\
\hline LDL-C (mg/dL) & $126.1 \pm 32.3$ & $129.7 \pm 39.1$ & 0.516 \\
\hline HDL-C (mg/dL) & $41.8 \pm 9.6$ & $41.2 \pm 11.4$ & 0.722 \\
\hline Triglyceride (mg/dL) & $155(99,231)$ & $154(98,226)$ & 0.884 \\
\hline $\begin{array}{l}\text { Duke treadmill score } \\
\text { (IQR) }\end{array}$ & $1(-2,3)$ & $-3(-7,0)$ & 0.001 \\
\hline METs & $10.6 \pm 2.04$ & $9.55 \pm 2.71$ & 0.004 \\
\hline Terminated HR, \% & $91.1 \pm 7.6$ & $90.1 \pm 10.4$ & 0.473 \\
\hline Sigma-shaped RCA, \% & $21(24.1)$ & 39 (44.3) & 0.005 \\
\hline
\end{tabular}

\section{Discussion}

Our study showed that, in the presence of $\mathrm{CT}$, the rate of false positivity was significantly higher, and the DTS was lower in patients with chest pain. Furthermore, the findings were more manifest as the number of vessels affected by tortuosity in coronary artery system increased, and the DTS tended to be lower in cases of LAD coronary artery involvement. The presence of RCA with sigma-shaped morphology was also shown to impact the exercise test negatively. Arterial tortuosity can be seen in various organ systems. Such tortuosities have been thought to be associated with genetic syndromes (13). However, ageing and hypertension have been known to be associated with tortuosity not only in the coronary arteries, but also in the cerebral, femoral and carotid arteries (14). Naturally, coronary arteries tend to be mildly more tortuous relative to other arterial systems to adapt to the cardiac cycle, that is, to be able to show flexion and extension (15). It has been speculated that the $C T$ might cause angina during exercise and false-positive results in ESTs. Increasing the angle and number of bends has been suggested to cause a significant energy loss during blood flow and lead to ischaemia

Table 2. Duke scores according to right coronary artery type, left anterior descending artery involvement and severity of tortuosity

\begin{tabular}{|l|l|l|}
\hline RCA type (study group) & $\mathbf{n}(\%)$ & Duke score \\
\hline C-shaped RCA & $115(65.7)$ & $0(-2,2)$ \\
\hline Sigma-shaped RCA & $60(34.3)$ & $-4(-8,0)$ \\
\hline p & - & $<0.001$ \\
\hline LAD involvement (tortuosity group) & $\mathbf{n}(\%)$ & Duke score \\
\hline Presence & $76(86.4)$ & $-3(-7,-1)$ \\
\hline Absence & $12(13.6)$ & $0(-2.75,1.75)$ \\
\hline p & - & 0.024 \\
\hline Severity of involvement (tortuosity & $\mathbf{n}(\%)$ & Duke score \\
\hline group) & $23(26.1)$ & $1(-2,2)$ \\
\hline One vessel & $40(45.5)$ & $-2(-5,-1)$ \\
\hline Two vessels & $25(28.4)$ & $-9(-9.5,-6.5)$ \\
\hline Three vessels & - & $<0.001^{*}$ \\
\hline p & & \\
\hline RCA: Right coronary artery; LAD: left anterior descending artery *for all groups
\end{tabular}

RCA: Right coronary artery; LAD: left anterior descending artery, *for all groups

Table 3. Comparison of groups based on the treadmill Duke score

\begin{tabular}{|l|l|}
\hline Study population $(\mathbf{n}=\mathbf{1 7 5})$ & Low-risk group $(\mathbf{n}=\mathbf{1 0 1})$ \\
\hline Presence of coronary tortuosity $(\mathrm{n} / \%)$ & $24(13.7)$ \\
\hline Sigma-shaped RCA $(\mathrm{n} / \%)$ & $17(16.8)$ \\
\hline C-shaped RCA $(\mathrm{n} / \%)$ & $84(83.1)$ \\
\hline Duke treadmill score $($ mean \pm std) & $7.96 \pm 2.70$ \\
\hline Tortuosity group $(\mathbf{n}=\mathbf{8 8})$ & Low risk group $(\mathbf{n}=\mathbf{2 4})$ \\
\hline LAD involvement $(\mathrm{n} / \%)$ & $15(62.5)$ \\
\hline Sigma-shaped RCA $(\mathrm{n} / \%)$ & $11(45.8)$ \\
\hline Three vessels involvement $(\mathrm{n} / \%)$ & $4(16.6)$ \\
\hline Duke treadmill score $($ mean \pm std) & $6.47 \pm 3.14$
\end{tabular}

\begin{tabular}{|l|l|}
\hline Intermediate and high-risk groups $(\mathbf{n}=\mathbf{7 4})$ & $\mathbf{p}$ \\
\hline $64(36.5)$ & 0.0001 \\
\hline $43(58.1)$ & 0.0001 \\
\hline $31(41.8)$ & 0.0001 \\
\hline$-3.34 \pm 4.84$ & 0.0001 \\
\hline Intermediate and high-risk groups $(\mathbf{n}=\mathbf{6 4})$ & $\mathbf{p}$ \\
\hline $61(95.3)$ & 0.002 \\
\hline $49(76.5)$ & 0.0001 \\
\hline $21(32.8)$ & 0.019 \\
\hline$-4.37 \pm 4.65$ & 0.0001 \\
\hline
\end{tabular}

RCA: Right coronary artery; LAD: left anterior descending artery, std: standard deviation 
due to reduction in distal perfusion pressure in the coronary vascular bed (4). It is not yet known whether the reduction in distal perfusion pressure is significant and leads to myocardial ischaemia. In association with the decreased diastolic filling due to increased heart rate during emotional or physical stress, increased tortuosity can lead to ischaemic symptoms by further reducing blood flow in the distal coronary vascular bed or by increasing coronary vascular resistance $(6,16,17)$ By contrast, the probability of acute coronary syndrome due to spontaneous coronary dissection and recurrence of dissection is higher in tortuous segments (18).

In studies investigating the relationship between atherosclerosis and tortuosity, the calcium score calculated by computed tomographic angiography was higher in tortuous coronary arteries (19), and the carotid intima-media thickness was increased in patients with CT (20). Likewise, the progression of atherosclerotic plaque has been suggested to intensify due to increased shear stress in the tortuous vessels, and the risk of consequential plaque rupture would be high (21). By contrast, in individuals with $\mathrm{CT}$, atherosclerotic stenosis in the tortuous segment was less than that in the non-tortuous region, and CT might have a protective role against atherosclerosis-induced vascular obstruction (22). Despite these, long-term follow-up studies showed that the presence of CT has no effect on the development of major cardiovascular events (2).

Studies have shown that CT was associated with chronic stable angina, typically resulting in increased chest pain increased during exercise and decreased chest pain with rest, and leading to reversible perfusion defects in myocardial perfusion scintigraphy (8).

In an investigation of patients with ischaemia on myocardial perfusion scintigraphy but with normal CA, the presence of CT resulted in 7-times more ischaemia. In these patients, the rate of ischaemia detection in stress echocardiography was higher (8). In another study, most of the patients with chest pain but without obstructive coronary artery disease were women, and the rate of $\mathrm{CT}$ in women was two-folds higher than in males (7). Although the groups were age- and sex-matched in our study, female sex was more common in the CT group albeit not statistically significant. Similar to previous studies, the proportion of hypertensive patients was higher in the CT group ( $p=0.043)$. Therefore, blood pressure regulation might be an effective treatment for controlling angina in these patients. Moreover, increasing coronary perfusion by decreasing the heart rate and prolonging the diastolic phase might be effective in controlling angina in patients with high heart rate and hypertension.

The rate of $\mathrm{CT}$ was higher in patients who underwent CA due to a positive EST, which was frequently used in practice, but were not found to have coronary artery disease. In addition, the CT angles were more severe in patients with a positive EST (23). In the same study, the number of tortuous bends higher in the group with ischaemic changes. Another study based on the EST found that the rates of ST depression and the changes in $\mathrm{T}$ wave were higher in patients with $\mathrm{CT}$, and the objective ischaemia findings correlated with the number of vessels affected by the tortuosity (24). In our study, the DTS decreased as the number of vessels affected by the tortuosity increased. Besides, the DTS was lower in patients with LAD coronary artery involvement. The moderate-to- high risk group has higher number of vessels affected by tortuosity, LAD coronary artery involvement, and proportion of sigma-shaped RCA.

Previous studies investigating the relationship between RCA morphology and atherosclerosis found that atherosclerotic plaque formation was more common in C-shaped RCA (10). The presence of C-shaped RCA has been reported as an independent predictor of the severity and extent of coronary artery disease (25). In support of these findings, the proportion of flow-mediated dilatation in the brachial artery in individuals with sigma-shaped RCA was better than that in those with C-shaped RCA (26). Given that the sigma-shaped RCA is a special naming for the $\mathrm{CT}$, the protective effect of $\mathrm{CT}$ against atherosclerosis can be considered more predominant. By contrast, because the DTS was lower in the exercise tests of the CT group, endothelial dysfunction resulting from decreased coronary flow after stress might be worse in this group. More studies are needed to assess the relationship between $\mathrm{CT}$ and atherosclerotic plaque formation.

The study involved a relatively small number of patients. Moreover, because the number of high-risk patients based on the DTS was low $(n=5)$, this group could not be considered separately. More comprehensive results could be obtained if myocardial perfusion scintigraphy was also performed. Likewise, the effect of the tortuosity on the distal flow could be evaluated more precisely if standard fractional flow reserve (FFR) was also measured. However, the rigidity of the FFR wire and the presence of CT could increase the likelihood of procedure-related complications in these patients.

\section{Conclusion}

The presence of $\mathrm{CT}$ might be a reason for a visit to the clinic due to recurrent angina. Controlling the risk factors in patients with positive EST and CT might be an effective approach to control angina. Further histopathological and molecular studies are needed to evaluate the relationship between $\mathrm{CT}$ and atherosclerosis.

\section{Ethics}

Ethics Committee Approval: The study protocol was approved by the Necmettin Erbakan University Meram Faculty of Medicine Institutional Ethics Board (decision no: 89, date: 24.05.2019).

Informed Consent: Written informed consent was obtained from all patients.

Peer-review: Externally and internally peer-reviewed.

Authorship Contributions: Surgical and Medical Practices - Y.A., A.I.; Concept - Y.A., A.I. A.S.G., A.Ö.; Design - Y.A., A.I. A.S.G., A.Ö.; Data Collection or Processing - Y.A., A.I., A.Ö.; Analysis or Interpretation - Y.A., A.S.G.; Literature Search - Y.A., A.I. A.S.G.; Writing - Y.A., A.I. A.S.G., A.Ö.

Conflict of Interest: No conflict of interest was declared by the authors.

Financial Disclosure: The authors declared that this study received no financial support.

\section{References}

1. Han HC. Twisted blood vessels: symptoms, etiology and biomechanical mechanisms. J Vasc Res 2012; 49: 185-97. 
2. Li Y, Shen C, Ji Y, Feng Y, Ma G, Liu N. Clinical implication of coronary tortuosity in patients with coronary artery disease. PLoS One 2011; 6: e24232.

3. Groves SS, Jain AC, Warden BE, Gharib W, Beto RJ 2nd. Severe coronary tortuosity and the relationship to significant coronary artery disease. W V Med J 2009; 105: 14-7.

4. Zegers ES, Meursing BT, Zegers EB, Oude Ophuis AJ. Coronary tortuosity: a long and winding road. Neth Heart J 2007; 15: 191-5.

5. Jakob M, Spasojevic D, Krogmann ON, Wiher H, Hug R, Hess OM. Tortuosity of coronary arteries in chronic pressure and volume overload. Cathet Cardiovasc Diagn 1996; 38: 25-31.

6. Cortese F, Gesualdo M, Acquaviva T, Cortese C, Ciccone A, Palumbo V, et al. Coronary Tortuosity: Normal Variant or Pathological Condition? A Case Report. ICFJ 2016; 6: 88-9.

7. Chiha J, Mitchell P, Gopinath B, Burlutsky G, Kovoor P, Thiagalingam A. Gender differences in the prevalence of coronary artery tortuosity and its association with coronary artery disease. Int J Cardiol Heart Vasc 2016; 14: 23-7.

8. Gaibazzi N, Rigo F, Reverberi C. Severe coronary tortuosity or myocardial bridging in patients with chest pain, normal coronary arteries, and reversible myocardial perfusion defects. Am J Cardiol 2011; 108: 973-8.

9. Shaw LJ, Peterson ED, Shaw LK, Kesler KL, DeLong ER, Harrell FE Jr, et al. Use of a prognostic treadmill score in identifying diagnostic coronary disease subgroups. Circulation 1998; 98: 1622-30.

10. Mark DB, Hlatky MA, Harrell FE Jr, Lee KL, Califf RM, Pryor DB. Exercise treadmill score for predicting prognosis in coronary artery disease. Ann Intern Med 1987; 106: 793-800.

11. Zaacks SM, Allen JE, Calvin JE, Schaer GL, Palvas BW, Parrillo JE, et al. Value of the American College of Cardiology/American Heart Association stenosis morphology classification for coronary interventions in the late 1990s. Am J Cardiol 1998; 82: 43-9.

12. Dvir D, Kornowski R, Gurevich J, Orlov B, Aravot D. Degrees of severe stenoses in sigma-shaped versus C-shaped right coronary arteries. Am J Cardiol 2003; 92: 294-8.

13. Wessels MW, Catsman-Berrevoets CE, Mancini GM, Breuning MH, Hoogeboom JJ, Stroink $\mathrm{H}$, et al. Three new families with arterial tortuosity syndrome. Am J Med Genet A 2004; 131: 134-43.
14. Del Corso L, Moruzzo D, Conte B, Agelli M, Romanelli AM, Pastine F, et al. Tortuosity, kinking, and coiling of the carotid artery: expression of atherosclerosis or aging? Angiology 1998; 49: 361-71.

15. Estrada APD, Lopes RO, Junior HV. Coronary tortuosity and its role in myocardial ischemia in patients with no coronary obstructions. Int J Cardiovasc Sci 2017; 30: $163-70$

16. Sho E, Nanjo H, Sho M, Kobayashi M, Komatsu M, Kawamura K, et al. Arterial enlargement, tortuosity, and intimal thickening in response to sequential exposure to high and low Wall shear stress. J Vasc Surg 2004; 39: 601-12.

17. Xie X, Yuanyuan W, Zhu H, Zhou H, Zhou J. Impact of coronary tortuosity on coronary blood supply: a patient-specific study. PLoS One 2013; 8: e64564.

18. Eleid MF, Guddeti RR, Tweet MS, Lerman A, Singh M, Best PJ, et al. Coronary Artery Tortuosity in Spontaneous Coronary Artery Dissection; Angiographic Characteristics and Clinical Implications. Circ Cardiovasc Interv 2014; 7: 65662 .

19. El Tahlawi M, Sakrana A, Elmurr A, Gouda M, Tharwat M. The relation between coronary tortuosity and calcium score in patients with chronic stable angina and normal coronaries by CT angiography. Atherosclerosis 2016; 246: 334-7.

20. Davutoglu V, Dogan A, Okumus S, Demir T, Tatar G, Gurler B, et al. Coronary artery tortuosity: comparison with retinal arteries and carotid intima-media thickness. Kardiol Pol 2013; 71: 1121-8.

21. Cunningham KS, Gotlieb AI. The role of shear stress in the pathogenesis of atherosclerosis. Lab Invest 2005; 85: 9-23.

22. Li Y, Feng Y, Ma G, Shen C, Liu N. Coronary tortuosity is negatively correlated with coronary atherosclerosis. J Int Med Res 2018; 46: 5205-9.

23. Hassan AKM, Abd-El Rahman H, Hassan SG, Ahmed TAN, Youssef AAA. Validity of tortuosity severity index in chest pain patients with abnormal exercise test and normal coronary angiography. Egypt Heart J 2018; 70: 381-7.

24. Tahlawi M, Gameel M, Ali W, Gouda M. Is there any relationship between coronary tortuosity and objective ischemia? Atheroscler Suppl 2017; 100: e4-5.

25. Demirbag R, Yilmaz R. Effects of the shape of coronary arteries on the presence, extent, and severity of their disease. Heart Vessels 2005; 20: 224-9.

26. Arbel $Y$, Dvir D, Feinberg MS, Beigel R, Shechter M. The association between right coronary artery morphology and endothelial function. Int J Cardiol 2007; 115: 19-23. 